Научная статья

УДК 336.717 .3

DOI: $10.18101 / 2304-4446-2021-2-66-76$

\title{
ДЕПОЗИТНЫЕ ОПЕРАЦИИ КОММЕРЧЕСКОГО БАНКА: АНАЛИЗ СОВРЕМЕННОГО СОСТОЯНИЯ И ТЕНДЕНЦИЙ РАЗВИТИЯ
}

\section{(C) Одоева Ольга Исааковна}

кандидат экономических наук, доцент, Бурятский государственный университет имени Доржи Банзарова Россия, 670000, г. Улан-Удэ, ул. Смолина, 24а bahaevao@mail.ru

\section{(C) Гомбоева Алла Николаевна}

кандидат экономических наук, доцент, Бурятская государственная сельскохозяйственная академия имени В. Р. Филиппова Россия, 670034, г. Улан-Удэ, ул. Пушкина, 8 allanicol@yandex.ru

(C) Постникова Любовь Валерьевна кандидат экономических наук, доцент, Российский государственный аграрный университет - MCXА имени К. А. Тимирязева Россия, 127550, г. Москва, Лиственничная аллея, 4 lpostnikova@gmail.com

Аннотация. В статье рассмотрено современное состояние депозитных операций коммерческого банка, исследованы теоретические аспекты, а также проблемы формирования депозитной политики коммерческого банка в настоящее время, определены основные проблемы реализации депозитной политики и тенденции их развития. Выявлена роль на рынке вкладов в нашей стране ПАО «Сбербанк», осуществлена оценка его финансового состояния, а также анализ депозитных операций банка, определена его доля в сегменте и изучена маркетинговая политика, рассмотрен ребрединг. Отмечена тенденция перетока накоплений населения из вкладов в фондовые биржи на инвестиции, в акции голубых фишек российской экономики и ПИФы. Сделана попытка разработать рекомендации для повышения эффективности депозитной политики коммерческих банков.

Ключевые слова: коммерческий банк, вклад, депозит, депозитная политика. начисление процентов, фондовый рынок, биржа, клиент, кредитный портфель, брокер

\section{Для цитирования}

Одоева О. И., Гомбоева А. Н., Постникова Л. В. Депозитные операции коммерческого банка: анализ современного состояния и тенденций развития // Вестник Бурятского государственного университета. Экономика и менеджмент. 2021. № 2. С. 66-76.

Депозитные операции являются традиционными, и существование банков без их привлечения невозможно, но в настоящее время, когда ставки по вкладам очень низкие, физические и юридические лица стараются найти новые источники дополнительного дохода или как минимум сберечь свои накопления от инфляции, соответственно наблюдается отток вкладов, что обусловливает необходи- 
О. И. Одоева, А. Н. Гомбоева, Л. В. Постникова. Депозитные операции коммерческого банка: анализ современного состояния и тенденций развития

мость дальнейших комплексных исследований. Конкуренция требует от бизнеса грамотно выстроенных технологий и высокого результата в любом виде деятельности, в том числе и в сфере депозитной политики, на которую влияет множество факторов, которые представлены в таблице 1.

Таблица 1

Факторы депозитной политики банка

\begin{tabular}{|l|l|}
\hline \multicolumn{1}{|c|}{ Внешние } & \multicolumn{1}{|c|}{ Внутренние } \\
\hline Размер учетной ставки ЦБ России & $\begin{array}{l}\text { Рентабельность, ликвидность и надежность } \\
\text { банка }\end{array}$ \\
\hline $\begin{array}{l}\text { Норматив обязательного резервирования } \\
\text { коммерческих банков }\end{array}$ & $\begin{array}{l}\text { Уровень процентных ставок по кратко- } \\
\text { срочным, среднесрочным и долгосрочным } \\
\text { депозитам }\end{array}$ \\
\hline Инфляционные ожидания & $\begin{array}{l}\text { Универсальность банковских депозитных } \\
\text { продуктов }\end{array}$ \\
\hline Динамика доходов граждан & Маркетинговая политика банка \\
\hline $\begin{array}{l}\text { Состояние и тенденции развития денежно- } \\
\text { кредитного рынка }\end{array}$ & Развитие банковских технологий \\
\hline $\begin{array}{l}\text { Объемы спекулятивных операций на фи- } \\
\text { нансовом рынке }\end{array}$ & $\begin{array}{l}\text { Разветвленность системы отделений и бан- } \\
\text { коматов самообслуживания }\end{array}$ \\
\hline $\begin{array}{l}\text { Политическая и экономическая ситуация в } \\
\text { стране }\end{array}$ & $\begin{array}{l}\text { Корпоративная и клиентская политика бан- } \\
\text { ка }\end{array}$ \\
\hline $\begin{array}{l}\text { Стабильность нормативно-правового зако- } \\
\text { нодательства }\end{array}$ & Квалификация персонала \\
\hline
\end{tabular}

Указанная систематизация факторов дает основания их разделить на депозитную политику на уровне государства, осуществляемую Центральным банком, и депозитную политику на уровне коммерческого банка.

Депозитная политика на уровне банка широко изучена российскими и зарубежными исследователями. Так, в работе Н. Н. Мартыненко разработана широкая классификация депозитных ресурсов. Среди предложенных классификационных признаков, отражающих характеристику привлеченных ресурсов с депозитных источников, заслуживающих внимания, можно выделить следующие: по секторам экономики; учитывая вид предприятия; по процентам; по месту нахождения клиентов: средства резидентов, нерезидентов [1, с. 56].

В новых реалиях многим банкам становится работать еще сложнее. Падение мировой экономики в 2020 г., по оценке МВФ, составило 3,5\% - после роста на $2,8 \%$ годом ранее. Экономический спад затронул как развитые, так и развивающиеся страны. Беспрецедентное влияние на экономическую активность оказало введение карантинных ограничений из-за распространения COVID-19. Крупнейшие центральные банки развитых стран перешли к смягчению денежнокредитной политики в ответ на связанные с распространением коронавируса экономические риски. В том числе большинство стран задействовало новые антикризисные инструменты. Программы, аналогичные количественному смягчению, впервые проводились в ряде развивающихся стран.

Страны, экспортирующие энергоресурсы (в частности, нефть), столкнулись как с шоком, вызванным пандемией и резким снижением цен на экспортные то- 
вары. Валюты ряда развивающихся экономик к концу 2020 г. не полностью отыграли ослабление, произошедшее на весеннем пике пандемии. В частности, российский рубль в конце 2020 г. был почти на $16 \%$ слабее, чем в начале года. Валюты Мексики и Бразилии ослабли по итогам 2020 г. на 6,5 и 21,5\% соответственно, валюта Турции - на $24,4 \%$. В то же время китайский юань укрепился почти на $7 \%{ }^{1}$.

Восстановление притока капитала на развивающиеся рынки (после беспрецедентного оттока в начале кризиса) происходило неравномерно и зависело как от вида финансовых инструментов, так и от конкретных стран-реципиентов. Самым уязвимым сегментом по оттоку капитала стали активы развивающихся рынков (кроме Китая) в национальных валютах. Накопленный поток капитала нерезидентов в этот сегмент достиг $-0,95 \%$ ВВП на пике пандемии, почти не восстановившись к концу 2020 г. $(-0,63 \%$ ВВП).

Рост мировой экономики в 2021 г., согласно прогнозу МВФ, составит 5,5\%, при этом развитые экономики вырастут на 4,3\%, развивающиеся - на $6,3 \%$.

На уровне нашего государства падение экономики в 2020 г. все же было значительно меньшим, чем в 2019 г., когда ВВП снизился на 7,8\%. Снижение ВВП в 2020 г. связано с ограничительными мерами, направленными на борьбу с короновирусной инфекцией, и падением мирового спроса на энергоресурсы, как отмечают в Росстате. Кроме того, расходы на конечное потребление упали у хозяйств на 8,6\%. В Росстате связывают это с падением потребительского спроса, преимущественно на непродовольственные товары и услуги ${ }^{2}$. Одной из причин снижения стало и то, что с 2018 г. в российскую отчетность был внедрен стандарт МСФО (IFRS) «Финансовые инструменты», из-за чего был завышен показатель выручки в 2019 г. - рекордный для сектора 1,9 трлн р. Для сравнения: рейтинговое агентство «Эксперт РА» при прогнозировании доналоговой прибыли не учитывал влияние МСФО и получил более скромный результат - 1,6 трлн р. Но в 2020 г. прибыль до налогообложения банков снизилась на 20-25\%, или 1,2-1,3 трлн р., соответственно снизился показатель доходности на капитал - c 14,6 до $11 \%{ }^{3}$.

В целом эксперты отмечают «существенное замедление темпов роста всех банковских рынков до 3-5\%. Такой спад снижает привлекательность банковского бизнеса и ведет к обострению конкуренции. Из-за краткосрочного характера размещения и высокой стоимости депозиты бюджетов не подходят для финансирования кредитного портфеля, поэтому рост доли бюджета в пассивах банковской системы сдерживает и рост кредитной активности» ${ }^{4}$

\footnotetext{
${ }^{1}$ Официальные данные Центрального банка России. URL: http://www.cbr.ru/analytics/ ?PrtId=bnksyst (дата обращения: 20.03.2021). Текст: электронный.

2 Официальный сайт Федеральной службы государственной статистики. URL: https://rosstat.gov.ru/folder/11192 (дата обращения: 05.04.2021). Текст: электронный.

3 Официальный сайт рейтингового агентства «Эксперт PA». URL: https://www.raexpert.ru/ratings/bankcredit/ (дата обращения: 07.04.2021). Текст: электронный.

${ }^{4}$ URL: https://vc.ru/marketing/163867-rebrending-sberbanka-kak-prevratit-tradicionnyy-brendv-innovacionnyy-semioticheskiy-analiz (дата обращения: 05.04.2021). Текст: электронный.
} 
О. И. Одоева, А. Н. Гомбоева, Л. В. Постникова. Депозитные операции коммерческого банка: анализ современного состояния и тенденций развития

Как уже отмечалось, ставки по банковским депозитам в России находятся «вблизи дна», дополнительное снижение будет происходить и в 2021 г., когда будут выходить существующие депозиты и меняться на текущую линейку.

Прогноз снижения доли вкладов в структуре безналичных сбережений граждан к 2023 г. - с 85 до 81\%, а роль инвестиций в фондовые рынки будет увеличиваться - общий объем накоплений россиян вырастет почти на $40 \%$. И, как итог, вкладчикам все сложнее рассчитывать на высокие доходы по своим вкладам в любой валюте.

Классическая депозитная политика теперь не является приоритетом, необходимы новые комбинированные банковские продукты, которые помогут привлечь средства населения.

Современная депозитная политика банка должна создавать условия для не рискованного вложения финансовых ресурсов субъектов рынка. Именно поэтому менеджмент депозитных ресурсов предполагает осуществление системного, динамического анализа объемов привлеченных депозитов. Яркий пример нового развития банка - это инновационные технологии Тинькоффбанка, Альфабанка, Точки и других.

Нововведения Сбербанка также свидетельствуют о его желании стать крупнейшей экосистемой в России. Новые сервисы и услуги госбанка позволят ему увеличить аудиторию и свои доходы. Это основано на прогнозах о поколении $\mathrm{Y}$ или миллиниалах, которые родились в начале нового тысячелетия и отличаются вовлеченностью в цифровые технологии. Ожидается, что к 2025 г. их будет 75\% среди работающего населения» ${ }^{1}$ При этом положение ПАО «Сбербанк» только укрепилось благодаря государственной поддержке. Доли рынка ПАО «Сбербанк» по состоянию на 1 января 2021 г. составили: 54\% - ипотека, $42 \%$ - розничные кредиты, $45 \%$ - розничные депозиты $66,2 \%$ - доля продаж потребительских кредитов в цифровых каналах; было 25\% (декабрь 2017), 45,6\% - доля продаж ипотеки в цифровых каналах, было 10,3\% (декабрь 2017). Число розничных клиентов ПАО «Сбербанк» в России превышает 127 млн человек и 10 млн за ее пределами, количество корпоративных клиентов Группы - более 1,1 млн в 22 странах присутствия ${ }^{2}$.

Три года назад ПАО «Сбербанк» начал масштабную трансформацию, направленную на развитие небанковских сервисов. Запущен новый бренд, который символизирует переход от исключительно финансового бизнеса к созданию экосистемы.

Состояние банка после трансформации отражает статистика, составленная журналом «The Banker», «Сбербанк» находится на 27-й строке рейтинга среди всех банков мира. Он является единственным российским банком, который попал в топ 30 рейтинга, а также является банком номер 1 по стране. В среднем

1 Официальный сайт Федеральной службы государственной статистики. URL: https://rosstat.gov.ru/folder/11192 (дата обращения: 05.04.2021). Текст: электронный.

2 Официальный сайт ПАО «Сбербанк». URL: https://www.sberbank.ru (дата обращения: 04.04.2021). Текст: электронный. 
примерно 50\% российского рынка инвестировано в «Сбербанке», а каждая треть организаций имеет розничные кредиты ${ }^{1}$.

Основные финансовые показатели ПАО «Сбербанк» за 2017-2020 гг. и тенденции их развития представлены на рисунке 1 (млн р.).

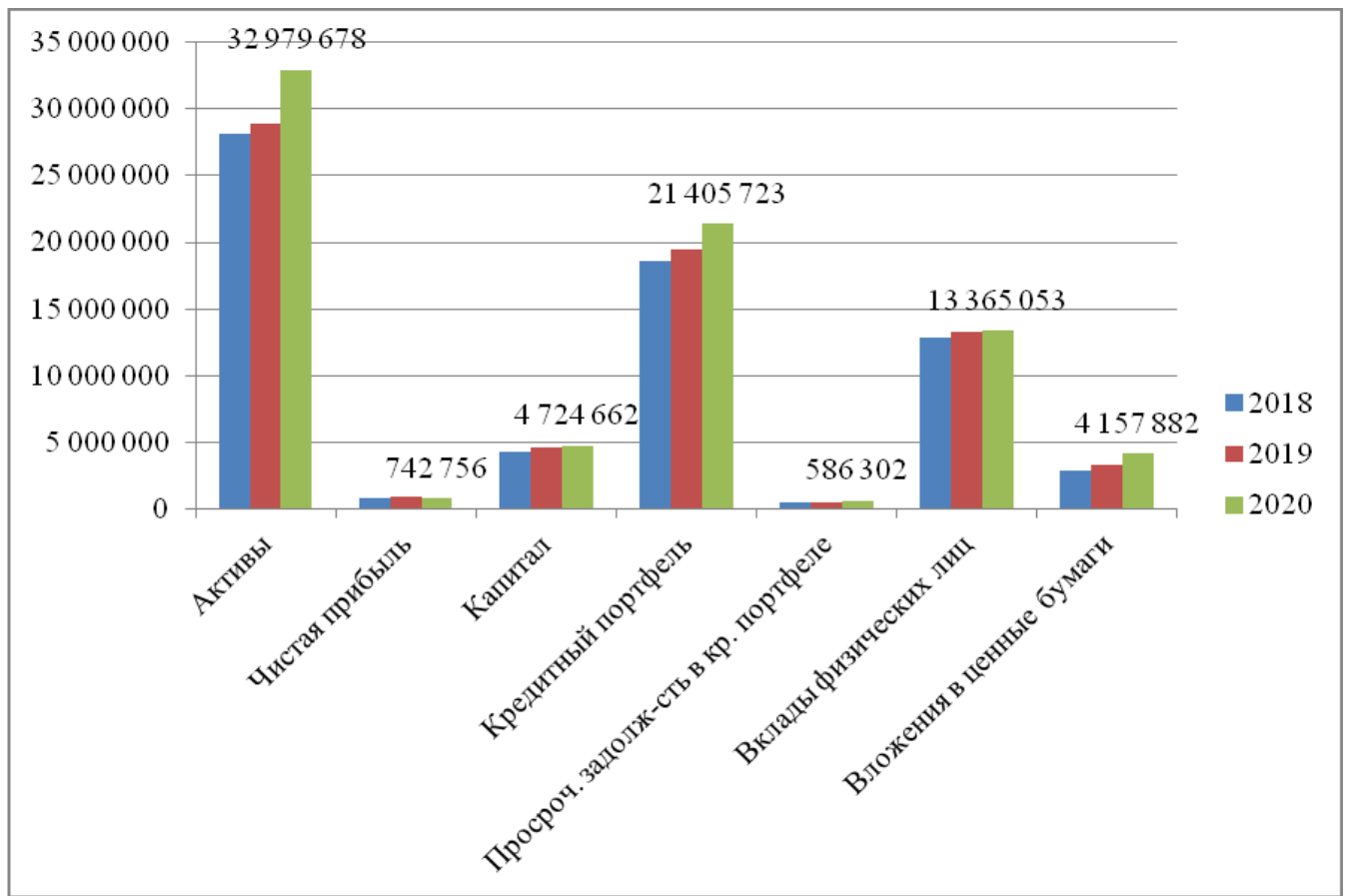

Рис. 1. Основные финансовые показатели ПАО «Сбербанк» за 2017-2020 гг.

Активы по итогам 2020 г. выросли на 14,1\% и составили 32,9 трлн р. Активы организации образовывают больше трети банковской системы страны (36\%), а сумма в общем банковском капитале определяется на уровне $35 \%$.

За исследуемый период в 2020 г. чистая прибыль ниже уровня 2019 г. на 88469 млн р., снижение составило 16,6\%, что связано с пандемией короновируса. Остальные показатели имеют стабильный рост. Можно отметить, что вклады населения остались практически на том же уровне $(+0,4 \%)$, зато вложения в ценные бумаги увеличились на 25,7\%, а кредитный портфель - на $10 \%$. Просроченная задолженность в кредитном портфеле также показала рост на 23,8\%, что тоже объяснимо кредитными каникулами для предпринимателей и населения, попавшего в трудное положение, связанное с пандемией. Сбербанк получает значительное преимущество от масштабной клиентской базы, высокого уровня цифровизации бизнеса, запаса прочности по капиталу и низкой стоимости процентных обязательств.

\footnotetext{
${ }^{1}$ URL: https://vc.ru/marketing/163867-rebrending-sberbanka-kak-prevratit-tradicionnyy-brendv-innovacionnyy-semioticheskiy-analiz (дата обращения: 05.04.2021). Текст: электронный.
} 
О. И. Одоева, А. Н. Гомбоева, Л. В. Постникова. Депозитные операции коммерческого банка: анализ современного состояния и тенденций развития

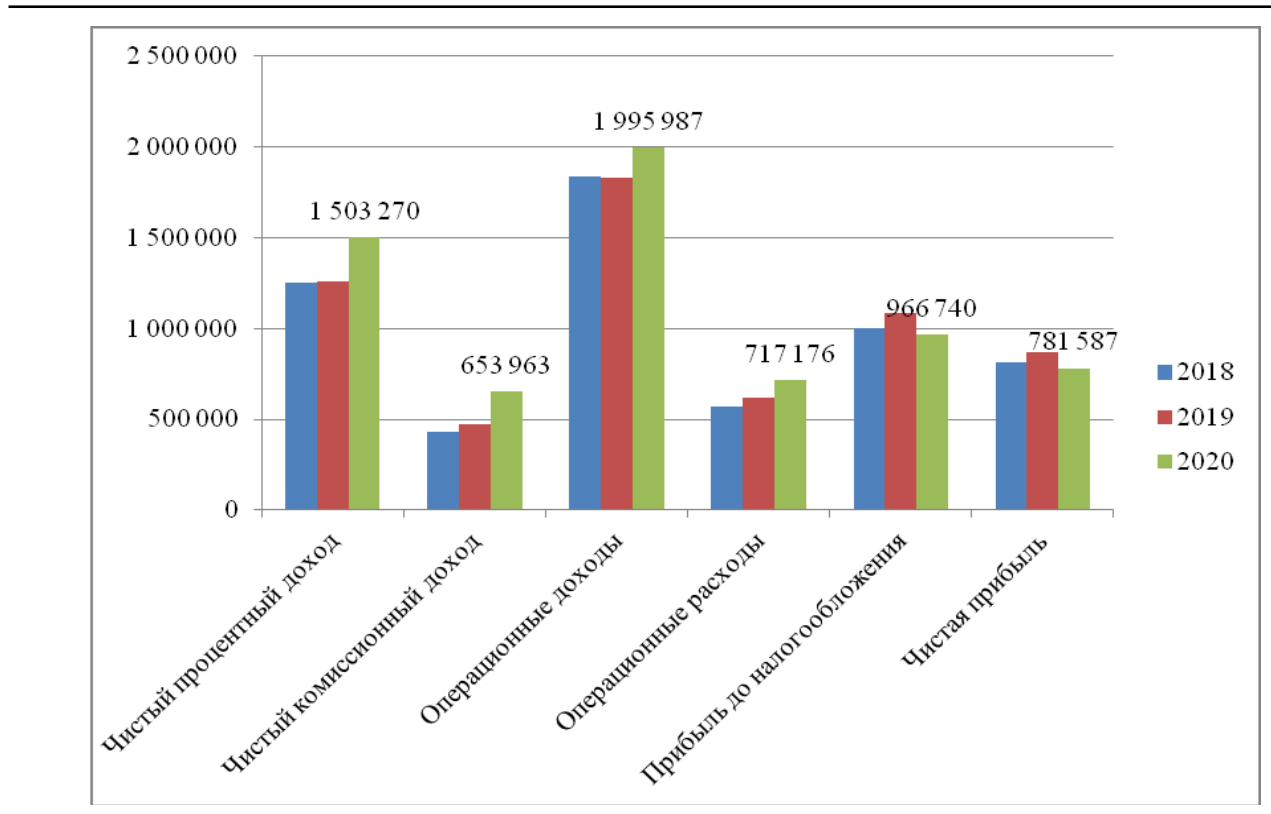

Рис. 2 Финансовые результаты ПАО «Сбербанк» за 2018-2020 гг., в млн р.

Анализ финансовых результатов (рис. 2) за 2018-2020 гг. показал, что отношение операционных расходов к доходам увеличилось на 1,8\% в 2019 г., отношение расходов к средним активам составило 2,2\%. За 2020 г. банк заработал 781,6 млрд р. чистой прибыли без учета событий после отчетной даты. Относительные показатели финансовых результатов показали, что рентабельность капитала составила 16,5\%, а рентабельность активов — 2,6\%. На результаты 2019 г. повлияло признание убытков в размере 69,8 млрд р. На результаты 2020 г. повлияло признание прибыли в размере 5,8 млрд р. от продажи актива.

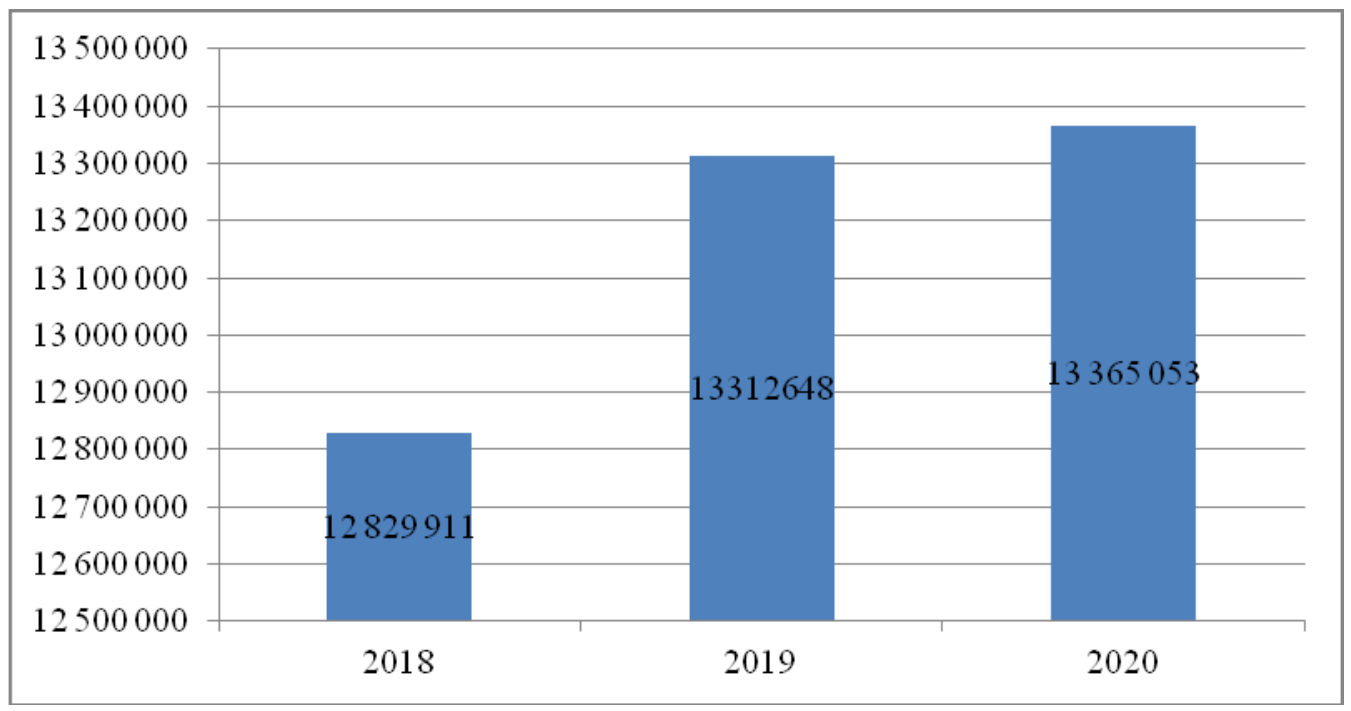

Рис. 3 Вклады физических лиц в ПАО «Сбербанк», млн р. 
Рассмотрев привлечение денежных ресурсов ПАО «Сбербанк» (рис. 3), видно, что если в 2019 г. в ПАО «Сбербанк» произошел рост вкладов населения по сравнению с 2018 г. на 3,76\%, то в 2020 г. он увеличился всего на $0,4 \%$. Это подтверждается аналитическими отчетами банка: $62,4 \%$ депозитов привлекается через Сбербанк-онлайн. На 1 января 2020 г. - 98,9 млн активных клиентов - физических лиц, что больше на 10\%, чем по состоянию на 1 января 2018 г. Количество активных дебетовых карт на 1 января 2020 г. - 123,1 млн, на 1 января 2018 г. - 102,4 млн (+18\%).

Управление активами в ПАО «Сбербанк» в 2020 г. отражено на рисунке 4.

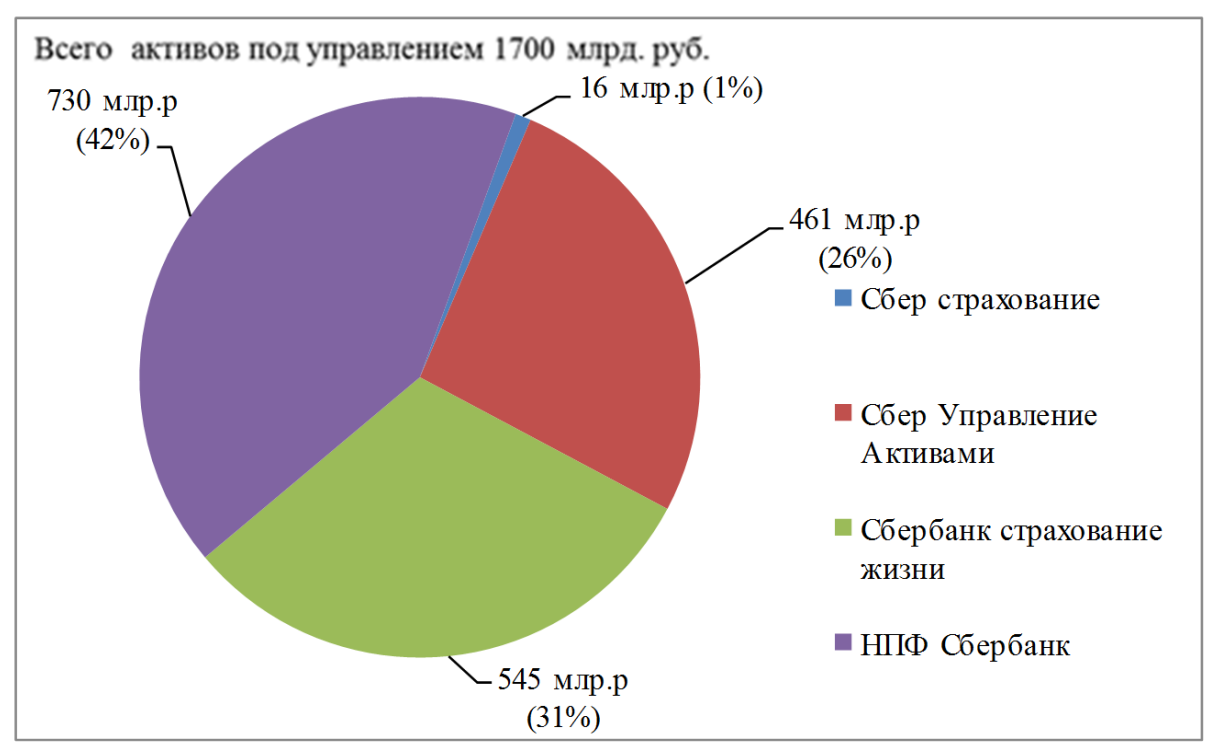

Рис. 4. Управление активами в ПАО «Сбербанк» в 2020 г.

ПАО «Сбербанк» занимает первое место на рынке страхования жизни 19 млн клиентов, а по прочему рисковому страхованию - 7 млн клиентов, пятое место на рынке инвестиционного страхования жизни - 700 тыс. клиентов. 3,5 млн брокерских счетов, 1,6 млн индивидуальных инвестиционных счетов (ИИС). Средства клиентов на брокерских счётах и ИИС выросли за 3 года с 0,38 до 1,86 трлн р.

С целью сокращения процесса оттока в 2020 г. был разработан новый продукт - инвестиционные облигации Сбербанка «ТОР Brands», доходность которых зависит от цен на акции крупнейших международных компаний. В рамках выпуска продукт приобрели более 6 тыс. клиентов на сумму более 4,4 млрд p.

В настоящее время активизировался процесс оттока сбережений населения из банковской системы в фондовый рынок, что связано с низкой доходностью по вкладам физических лиц. Сбербанк первым в России запустил биржевые ПИФы с целью сохранения сбережений населения. Четыре ПИФа вошли в топ 10 по привлеченным средствам от инвесторов: «Сбалансированный», «Денежный», биржевой фонд «Индекс МосБиржи государственных облигаций» и «Долларовые облигации». Три фонда вошли в топ 10 ПИФов, которые показали самую высокую доходность с начала года (среди фондов со стоимостью чистых активов 
О. И. Одоева, А. Н. Гомбоева, Л. В. Постникова. Депозитные операции коммерческого банка: анализ современного состояния и тенденций развития

свыше 1 млрд р.): «Потребительский сектор» $(+56,76 \%)$ «Глобальный интернет» $(+56,26 \%)$, «Биотехнологии» $(45,97 \%)$.

По итогам 2020 г. интегральный показатель качества управления активами составил 1,17 относительно топ-компаний конкурентной группы.

Основная тенденция притока клиентов на фондовый рынок, связанная с падением депозитных ставок, представлена на рисунке 5.

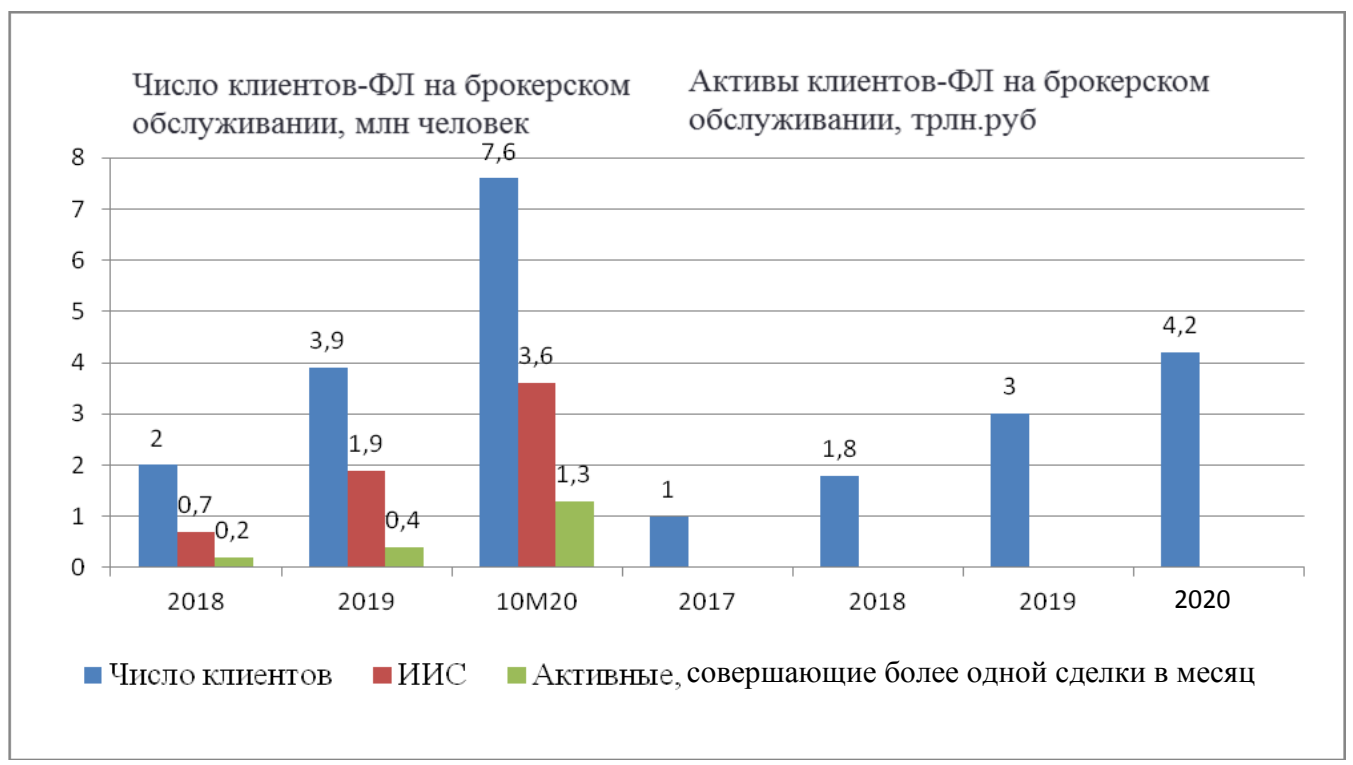

Рис. 5. Клиенты и их активы на брокерском обслуживании в ПАО «Сбербанк»

Как видно на рисунке 5, тенденция перетока клиентов из банковских продуктов на рынок ценных бумаг уже была заметна и в 2019 г., но в 2020 г. этот процесс заметно ускорился. По данным на 9 месяцев 2020 г., число клиентов и индивидуальные инвестиционные счета увеличились почти в два раза, а активные сделки - в 3,25 раза. Активы на брокерском обслуживании увеличились более чем в 1,4 раза. По итогам 2020 г. число клиентов насчитывается 8 млн, при этом активен только каждый пятый трейдер, а по $40 \%$ счетов пока не наблюдается никакой активности. Тем не менее в условиях непривычно низких рублевых ставок количество самостоятельных инвесторов продолжает возрастать. Этому способствует также все еще невысокий уровень вовлеченности населения в финансовые рынки, точка насыщения по-прежнему далека.

Как недостаток стоит отметить, что переток массового инвестора на фондовый рынок несет и свои риски. Хотя брокерские компании заманивают клиентов обещаниями более высоких доходов, в реальности большинство начинающих инвесторов не обладает достаточными компетенциями для инвестиций на фондовом рынке. В поисках более высокой доходности начинающие инвесторы систематически составляют достаточно рискованные портфели: в их составе часто преобладают акции, что приводит к высокому влиянию рыночной волатильности на финансовый результат. Часто они выбирают неоптимальный момент для захода на рынок, а столкнувшись с падением стоимости ценных бумаг, продают их, фиксируя убыток. Такое поведение может быть вызвано тем, что на рынок идут 
средства накоплений на будущие покупки, в результате короткий горизонт инвестирования в сочетании с рискованной структурой портфеля ведут к убыткам, а не к обещанным доходам.

Необходимы программы повышения финансовой грамотности, которые бы помогли избежать разочарования начинающих инвесторов, обеспечив долгосрочную базу розничных инвесторов для развития российского фондового рынка.

В целом в результате проведенного в 2020 г. рейбрединга Сбербанк дает следующие прогнозы (рис. 6).

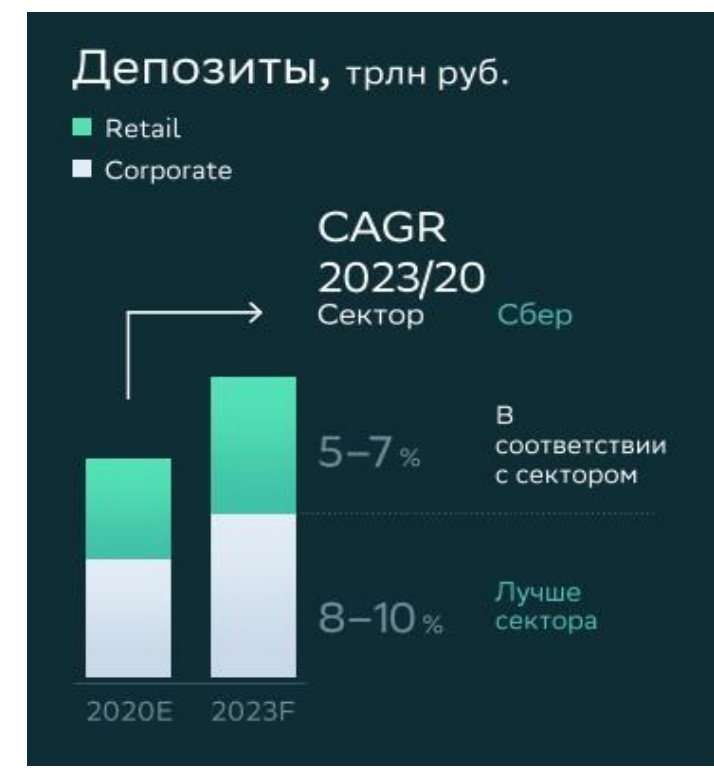

Рис. 6. Прогноз экспертов ПАО «Сбербанк» по развитию депозитов [3]

Вследствие фокуса на цифровую трансформацию и рост клиентской базы произойдет рост банковских продаж в 2,7 раза, а уровень удовлетворенности клиента - 1,2 раза.

Происходит отказ от классической традиционной политики, банк пытается сформировать единый взгляд на клиентов и соединить потребности людей, бизнеса и страны решениями Сбера через соединение сервисов, данных о клиентах, развитие каналов и выстраивание общих процессов.

Для внедрения новой бизнес-модели Сбер инвестирует в развитие технологий, команды и реализует ESG-повестку. Сбер коснулся не только изменения логотипов, но и всей инфраструктуры. Сбер пытается стать новой технологической экосистемой, благодаря чему банк смог создать ряд новых и уникальных продуктов, которые включают облачные системы, Foodtech\&Mobility, кибербезопасность, рисковые страхования, управление благосостоянием и брокерские услуги, e-commerce, е-образование, health, развлечения, а также платежи и переводы. Так, например, появились новые продукты, такие как Sber Food, Sber Cloud, Сбер Авто, Сбер здоровье, Сбер маркет и Сбер логистика. Также ко всему этому был придуман новый слоган «Сбер. Всегда рядом!». Все сервисы экосистемы постро- 
О. И. Одоева, А. Н. Гомбоева, Л. В. Постникова. Депозитные операции коммерческого банка: анализ современного состояния и тенденций развития

ены на единой цифровой технологической платформе с использованием больших данных и искусственного интеллекта. Каждая из этих технологий позволит «Сбер» увеличить объем ВВП при минимальном количестве затрат.

Технология больших данных или в отдельном значении big data позволит Сбербанку существенно ускорить рост ВВП примерно на $0,3-2,4 \%$ на российском рынке к 2024 г. Все будет зависеть от того, какого сценария будет придерживаться государство.

Современная депозитная политика банков требует усовершенствования и со стороны законодательства и государственной власти. Среди основных направлений ее повышения можно назвать поддержание политической стабильности в стране, поскольку эффективная деятельность органов государственной власти, соблюдение ими четкой позиции, своевременное реагирование на непредвиденные ситуации влияют положительно на стабилизацию экономики, что приводит к повышению темпов экономического роста.

Отмечаем, что внедрение системы страхования банковских депозитов обусловлено общим спадом доверия к банкам, необходимостью стабилизации их финансовых ресурсов и оказания помощи банкам, которые находятся в состоянии банкротства, необходимостью защиты депозитных вкладов клиентов в случае банкротства банка.

В настоящее время население изменило поведение на рынке банковских сбережений. В пандемийный 2020 год средства россиян на рублевых и валютных счетах в Сбербанке резко возросли из-за перетока средств с депозитов, снижения трат на поездки, накопления денег на жилье. Тенденцию подтверждают и другие банки.

Современная депозитная политика банка должна создавать условия для нерискованного вложения финансовых ресурсов субъектов рынка. Именно поэтому менеджмент депозитных ресурсов предполагает осуществление системного, динамического анализа объемов привлеченных депозитов.

Таким образом, современное состояние и тенденции развития депозитных операций коммерческого банка выходят за рамки классического понимания простых вкладов с начислениями процентов. Клиентоцентричность становится основной тенденцией развития банковского сектора, где в условиях конкуренции и жесткого нормативного регулирования выживают только те, кто предлагает комплексные услуги, в том числе и по управлению депозитами.

\section{Литература}

1. Банковское дело: учебник для вузов: в 2 частях / Н. Н. Мартыненко, О. М. Маркова, О. С. Рудакова, Н. В. Сергеева; под редакцией Н. Н. Мартыненко. 2-е изд., испр. и доп. Москва: Юрайт, 2020. Ч. 1. 217 c. URL: https://urait.ru/bcode/451916/p.56 (дата обращения: 07.04.2021). Текст: электронный.

Статья поступила в редакцию 12.04.2021; одобрена после рецензирования 28.04.2021; принята к публикации 28.04.2021. 


\section{DEPOSIT OPERATIONS OF A COMMERCIAL BANK: \\ ANALYSIS OF THE CURRENT STATE AND DEVELOPMENT TRENDS}

Olga I. Odoeva

Cand. Sci. (Econ.), A/Prof.,

Dorzhi Banzarov Buryat State University

24a Smolina St., Ulan-Ude 670000, Russia

bahaevao@mail.ru

Alla N. Gomboeva

Cand. Sci. (Econ.), A/Prof.,

Filippov Buryat State Agricultural Academy

8 Pushkina St., Ulan-Ude 670034, Russia

allanicol@yandex.ru

\section{Lyubov V. Postnikova}

Cand. Sci. (Econ.), A/Prof.,

Russian State Agrarian University - Timiryazev Moscow Agricultural Academy

4 Listvennichnaya Alley, Moscow, 127550, Russia

lpostnikova@gmail.com

Abstract. The article analyzes the current state of deposit operations in commercial banks, studies the theoretical aspects, as well as the problems of deposit policy formation in commercial banks, identifies the main problems of implementing deposit policy and their development trends. We have revealed the role of PJSC "Sberbank" in the deposit market of our country, assessed its financial state, analyzed the bank's deposit operations, its share in the segment and marketing policy, and considered rebranding. There is a tendency for the population's savings to flow from deposits to stock exchanges, shares of Russian blue-chip companies and mutual funds. We have made an attempt to develop recommendations for improving the efficiency of deposit policy in commercial banks.

Keywords: commercial bank, deposit, deposit policy, interest accrual, share market, stock exchange, client, advances portfolio, broker

For citation

Odoeva O. I., Gomboeva A. N., Postnikova L. V. Deposit Operations of A Commercial Bank: Analysis of the Current State and Development Trends. Bulletin of Buryat State University. Economy and Management. 2021; 2: 66-76 (In Russ.).

The article was submitted 12.04.2021; approved after reviewing 28.04.2021; accepted for publication 28.04.2021. 